\title{
Obraz Jezusa w Ewangeliach kanonicznych a kwestia homoseksualna
}

\author{
Jesus' Portrait in the Canonical Gospels and the Issue of Homosexuality
}

\author{
JANUSZ KRĘCIDŁO \\ Uniwersytet Kardynała Stefana Wyszyńskiego w Warszawie \\ j.krecidlo@uksw.edu.pl; ORCID: 0000-0002-0913-5513
}

\begin{abstract}
Streszczenie: Autor artykułu stawia sobie za cel badawczy eksplorację problematyki stosunku Jezusa do homoseksualizmu. Chociaż w Ewangeliach kanonicznych nie znajdujemy ani jednej wypowiedzi, w której Jezus explicite odnosiłby się do aktów lub osób homoseksualnych, to jednak przeprowadzone w artykule analizy pozwalają na wyciągnięcie wniosku o Jego negatywnej ocenie relacji homoseksualnych. Artykuł składa się z dwóch części. W pierwszej są zaprezentowane i krytycznie ocenione prace współczesnych autorów, którzy na podstawie tendencyjnej interpretacji niektórych perykop z Ewangelii kanonicznych przypisują Jezusowi homoerotyczne relacje. W drugiej części artykułu autor najpierw uzasadnia względne "milczenie” Jezusa na temat relacji homoseksualnych faktem podtrzymywania przez Niego starotestamentowych standardów etycznych w tym zakresie, a następnie analizuje fragmenty Ewangelii, z który można implicite wnioskować o Jego braku akceptacji aktów homoseksualnych.
\end{abstract}

Słowa kluczowe: Jezus, homoseksualizm, Ewangelie kanoniczne

Abstract: The author of the article aims to explore the issue of Jesus' attitude toward homosexuality. Although in the canonical Gospels we do not find a single statement in which Jesus explicitly refers to homosexual acts or persons, the analyses carried out in the article allow us to conclude that He in fact held a negative attitude toward homosexual relations. The article consists of two parts. The first presents and critically evaluates the works of contemporary authors who, on the basis of tendentious interpretations of certain pericopes from the canonical Gospels, attribute to Jesus himself homoerotic relationships. In the second part of the article, the author first explains Jesus' relative "silence" about homosexual relations by the fact that He embraced and upheld the Old Testament ethical standards on this point. Finally, an analysis is offered of several passages from the Gospels, from which one can conclude, implicitly, that He did not accept homosexual acts.

Keywords: Jesus, homosexuality, canonical Gospels

Przedmiotem niniejszego przyczynku jest odpowiedź na pytanie: Jaki był stosunek Jezusa do homoseksualizmu? Przedstawimy argumenty za tym, że choć Jezus nie wypowiadał się explicite na temat relacji homoseksualnych, to jednak można z całą pewnością skonstatować, że implicite tę tematykę podejmował i że Jego opinia o relacjach homoseksualnych była negatywna. By to wykazać, najpierw poddamy krytycznej ewaluacji poglądy autorów, którzy na podstawie stronniczej lektury niektórych perykop Ewangelii kanonicznych, przypisują Jezusowi homoseksualną tożsamość i relacje. Następnie uzasadnimy względne „milczenie” Jezusa na temat relacji homo- 
seksualnych faktem jego zgodności z nauczaniem autorów Starego Testamentu. Na końcu poddamy analizie perykopy, z których można pośrednio wnioskować o negatywnej ocenie relacji homoseksualnych przez Jezusa.

\section{Ocena argumentów autorów przypisujących Jezusowi homoseksualną tożsamość i relacje}

Amerykański teolog protestancki, pastor i aktywny działacz środowisk homoseksualnych, Theodore W. Jennings, opublikował w 2003 r. monografię, w której stronniczo interpretuje kilka fragmentów Ewangelii kanonicznych w perspektywie tezy, że Jezus był homoseksualistą ${ }^{1}$. Monografia ta zbiera i rozwija większość przytaczanych w tej części artykułu argumentów innych autorów, z którymi chcemy tu polemizować.

Przedstawiciele środowisk homoseksualnych wystarczającą przesłankę za homoseksualną tożsamością Jezusa upatrują w tym, że w trzech Ewangeliach synoptycznych tylko jeden raz pada stwierdzenie, że ich główny bohater kogoś kochał. Stwierdzenie to wypowiada ewangelista Marek w perykopie 10,17-22, mówiącej o spotkaniu Jezusa $\mathrm{z}$ bogatym młodzieńcem. Kluczową $\mathrm{z}$ punktu widzenia tezy Jenningsa jest wypowiedź w Mk 10,21: „Jezus zaś, zobaczywszy go, umiłował go i powiedział mu

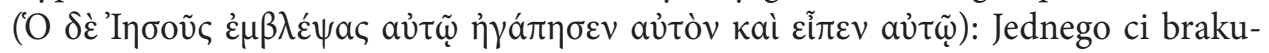
je. Idź, sprzedaj wszystko, co masz, i rozdaj ubogim, a będziesz miał skarb w niebie. Potem przyjdź i chodź za Mną". Jennings twierdzi, że jedyne rozsądne poszukiwanie sensu tego tekstu powinno prowadzić w kierunku uznania, że Jezus miał z bogatym młodzieńcem homoerotyczną relację̨ ${ }^{2}$. Interpretacja ta opiera się na jednym argumencie - okoliczności, że o nikim innym w Ewangelii Marka nie jest powiedziane, że Jezus go kochał. Jest to jednak argument zbyt słaby wobec wielości i siły argumentów przeciwnych wyciąganiu na podstawie tego tekstu wniosku o homoseksualnej relacji Jezusa z owym młodzieńcem. Wypowiedź Mk 10,21 powinna być czytana i interpretowana w kontekście całej perykopy Mk 10,17-22, z której jasno wynika, że: 1) bogaty młodzieniec nie znał wcześniej Jezusa i spotyka Go po raz pierwszy, padając przed nim na kolana i pytając, co ma czynić, aby osiągnąć życie wieczne $(10,17) ; 2)$ nie pozostaje on również przy Jezusie po usłyszeniu polecenia sprzedania wszystkiego co ma i rozdania ubogim, jako warunku pójścia za Nim $(10,21)$. Zatem kontekst opowiadanego epizodu wyraźnie wskazuje, że nie było żadnej relacji (nawet zwykłej znajomości) pomiędzy Jezusem a owym młodzieńcem. Drugi argument przeciwko

Zob. Jennings, The Man Jesus Loved.

2 Zob. Jennings, The Man Jesus Loved, 108: „The homoerotic interpretation of this episode [Mark 10:17-22] is virtually required if we are to account for the singularity of Jesus' love for just this person in the Gospel of Mark". 
tezie o homoseksualnej relacji Jezusa $\mathrm{z}$ bogatym młodzieńcem jest natury filologicznej. Argument T. Jenningsa za tą tezą opiera się na literalnej interpretacji wypowiedzi „umiłował go" $(10,21)$. W tekście greckim występuje tu czasownik ảyatáw, który zgodnie z klasycznym rozróżnieniem kompetencji semantycznych czasowników

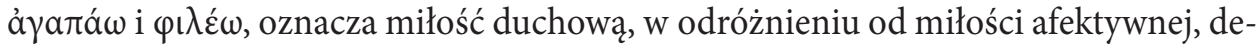
sygnowanej przez ten ostatni ${ }^{3}$. Suponowanie relacji homoseksualnych w epizodzie Mk 10,17-22 jest zatem wtłaczaniem w ten tekst treści, których w nim absolutnie nie ma. Jest to zwykła manipulacja.

Adrian Thatcher w opublikowanej w 2008 r. książce The Savage Text. The Use and Abuse of the Bible (Blackwell Publishing) twierdzi, że jednym z nadużyć egzegezy biblijnej jest to, że jest ona homofobiczna ${ }^{4}$. Przykład takiej egzegezy widzi w niewłaściwej - w jego mniemaniu - interpretacji epizodu z Ewangelii św. Marka o młodzieńcu, który szedł za Jezusem po pojmaniu Go w Getsemani. Kiedy ów młodzieniec, odziany prześcieradłem na gołym ciele, szedł za Jezusem, próbowano go pochwycić. On jednak, zostawiwszy prześcieradło, uciekł (zob. Mk 14,51-52). Thatcher uznaje za błędne podawane przez egzegetów propozycje wyjaśnienia tego skądinąd intrygującego epizodu i uważa, że powinno się go interpretować jako wyraźną aluzję adresowaną do czytelnika odnośnie do szczególnie bliskiej homoerotycznej relacji Jezusa z owym młodzieńcem ${ }^{5}$. Nie podaje jednak na poparcie swojej tezy żadnych racjonalnych argumentów. Taki kierunek wyjaśniania tego tekstu zupełnie neguje całą, opartą na solidnych podstawach, wieloaspektową tradycję interpretacyjną na rzecz czysto subiektywnej lektury.

Kluczową w interpretacji Mk 14,51-52 wydaje się być sprawa tożsamości owego młodzieńca. Jedni egzegeci odnoszą określający jego tożsamość grecki termin

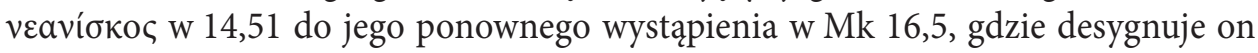
anielską postać informującą kobiety, że ciała Jezusa nie ma w grobie, gdyż zmartwychwstał ${ }^{6}$. Stąd też młodzieniec w Mk 14,51 może oznaczać po prostu anioła ${ }^{7}$ - na co wskazuje także brak ubrania prócz okrycia w postaci lnianego płótna (gr. $\sigma \iota v \delta \omega ́ v)$.

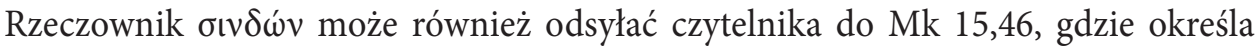
lniane płótno, w które zostało owinięte ciało Jezusa przed złożeniem do grobu. W Mk 14,51-52, poprzez postać anielskiego młodzieńca ubranego w lniane płótno, autor może więc chcieć intratekstualnie odesłać czytelnika do męki i śmierci Jezusa.

3 Do takich konkluzji dochodzi Ceslas Spicq w swojej obszernej trzytomowej monografii: AGAPH dans le Nouveau Testament.

4 Thatcher, The Savage Text, 15-36.

5 Thatcher, The Savage Text, 33: „an apparent allusion to the typical recipient of homoerotic attention ... at a decisive moment in the passion of Jesus, and with the suggestion of a particularly close relationship between Jesus and this youth".

6 Zagadnienie to omawia kompetentnie Adam Kubiś („Człowiek czy anioł?”, 385-420).

7 Bruce J. Malina i Richard L. Rohrbaugh (Social-Science Commentary, 214) wysuwają przypuszczenie, że ów anioł to anioł stróż Jezusa. 
Z uwagi na to, że czynność pójścia owego młodzieńca za Jezusem jest oddana

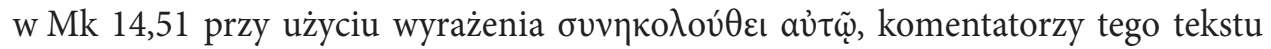
próbują utożsamić go z którymś z najbliższych uczniów Jezusa. Interpretacja taka

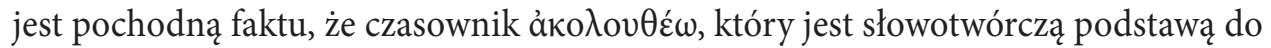

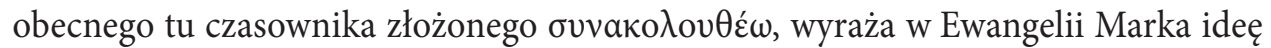
uczniostwa jako naśladowania Jezusa ${ }^{8}$. W związku z tym niektórzy egzegeci utożsamiają owego młodzieńca z Janem, synem Zebedeusza, inni z Jakubem, bratem Pańskim, jeszcze inni z Janem Markiem. W tym ostatnim przypadku chodziłoby o samego ewangelistę, który uwiarygodniałby się w ten sposób wobec czytelnika jako bezpośredni uczestnik tych wydarzeń 9 . Są także komentatorzy, którzy widzą w postaci tego młodzieńca symbol samego Jezusa lub (z perspektywy Kościoła popaschalnego) symbol chrześcijanina przechodzącego inicjację chrzcielną ${ }^{10}$.

Każda z przytoczonych tu możliwości zasługuje na uwagę. Najbardziej prawdopodobna wydaje się być propozycja interpretacji postaci tego młodzieńca jako symbolu najbliższych uczniów Jezusa, którzy opuścili Go w godzinie próby i stali się nadzy, tzn. zasługują na zawstydzenie, gdyż okazali się nielojalni wobec swojego Mistrza $^{11}$. Po przeglądzie owych propozycji interpretacyjnych należy stwierdzić, że nic w komentowanym tekście nie upoważnia czytelnika do wyciągania wniosków o homoseksualnej relacji Jezusa i owego młodzieńca.

Troje autorów - Nancy Wilson, Robert Goss i Steve Wells - twierdzi, że na podstawie lektury Ewangelii Jana 11,1-12,12 można wyciągnąć wniosek o homoseksualnej relacji Jezusa z Łazarzem. Wilson uważa nawet, że Jezus był biseksualistą, gdyż utrzymywał także relacje seksualne z mieszkającymi z Łazarzem lesbijkami Martą i Marią. Tezy te wysuwają wspomniani autorzy na podstawie faktu, że Jezus miał przyjazne kontakty z tymi, zamieszkującymi razem ludźmi, a przede wszystkim

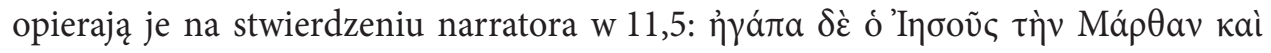

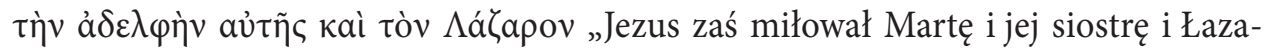
rza”. Przyjrzyjmy się bliżej ich argumentacji i poddajmy ją krytycznej ocenie. Doktor N. Wilson, moderatorka Metropolitan Community Churches w USA, utrzymuje, że Jezus miał platoniczną wyłączną relację homoseksualną z Łazarzem. Wręcz dziwi się, jak można czytać J 11 i nie wyobrazić sobie, że Jezus miał z Łazarzem uczuciową erotyczną relację ${ }^{12}$. Taką lekturę J 11 proponuje także były jezuita i aktywista środowisk

8 Zob. Donahue - Harrington, The Gospel of Mark, 416-417.

9 Tak sugeruje np. Richard T. France (The Gospel of Mark, 595-596).

10 Szeroko na temat różnych identyfikacji i teologicznych interpretacji tej postaci piszą: Kubiś, „Człowiek czy anioł?", 385-420; Perego, La nudità necessaria.

11 W Biblii nagość jest symbolem wstydu. Zob. np. Am 2,16. Por. Ostański, „Epizod o nagim młodzieńcu”, 209-223.

12 Zob. Wilson, Outing the Bible, 107, 110-111: „Did he [Lazarus] and Jesus have a platonic but distinctly homosexual relationship?... How is it possible to read over and over about this man [Lazarus] whom he [Jesus] loved and not imagine there might have been at least some dimension of passion and eroticism connected with his feelings". 
homoseksualnych R.E. Goss ${ }^{13}$. Ten sposób interpretacji wsparł australijski psycholog i mówca motywacyjny S. Wells, twierdzący, że J 11 pozwala wnioskować o intymnej homoseksualnej relacji Jezusa $z$ Łazarzem ${ }^{14}$. Jeszcze dalej idzie N. Wilson w tekście zamieszczonym na stronie Metropolitan Community Church, gdzie spekuluje, że stwierdzenie z J 11,5: „Jezus miłował Martę i jej siostrę i Łazarza”, wskazuje nie tylko na homoseksualną relację Jezusa z Łazarzem, lecz także na to, że owe kobiety nie były $\mathrm{w}$ istocie rodzonymi siostrami, lecz zamieszkującą razem parą lesbijek ${ }^{15}$. Stąd zaś autorka wnioskuje, że Jezus był nie tylko homoseksualistą, ale biseksualistą ${ }^{16}$.

Dla poparcia swoich tez autorzy ci nie podają żadnych rzeczowych argumentów, z którymi można by polemizować. Cała argumentacja opiera się na wyciągnięciu fał-

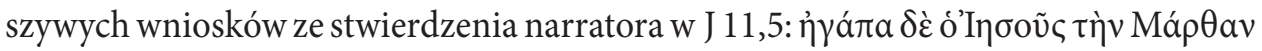

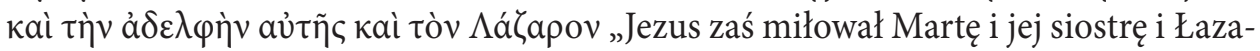
rza”. Użyty tu czasownik ảyatáw określa z pewnością relację duchową Jezusa z tym rodzeństwem. Natomiast w 11,36 Żydzi, którzy byli świadkami wrażliwości Jezusa z powodu śmierci przyjaciela Łazarza (11,35 - „Jezus zapłakał”), stwierdzili ‘́ $\delta \varepsilon \pi \tilde{\omega} \varsigma$

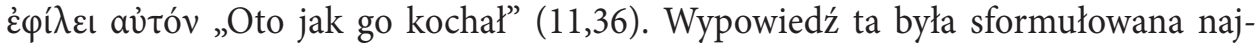
prawdopodobniej $\mathrm{w}$ języku aramejskim, a ewangelista używając czasownika $\varphi \iota \lambda \varepsilon^{\prime} \omega^{17}$, z pewnością chciał zakomunikować czytelnikowi, że Jezusa łączyła z Łazarzem więź przyjaźni (semantyczna kompatybilność czasownika $\varphi \iota \lambda \varepsilon ́ \omega$ z rzeczownikiem $\varphi \iota \lambda i ́ a-$ „przyjaźńn" ${ }^{18}$. Nie ma tu żadnych podstaw, by wyciągać wnioski o homoseksualnej (nawet czysto platonicznej) naturze ich relacji. Zupełnie pozbawione podstaw jest też zanegowanie tego, że Łazarz, Maria i Marta byli naturalnym rodzeństwem na rzecz tezy o wolnym związku homoseksualisty i dwóch lesbijek, po to, by uczynić z Jezusa biseksualistę. Nie trzeba dużego egzegetycznego wyrobienia, by stwierdzić, że lektura J 11 forsowana przez owych autorów jest czysto ideologiczna - próbuje wyciągać z tekstu treści, których w nim nie ma.

Niektórzy autorzy wyprowadzają wniosek o homoseksualnych skłonnościach Jezusa na podstawie tendencyjnej interpretacji Jego relacji z Umiłowanym Uczniem ${ }^{19}$

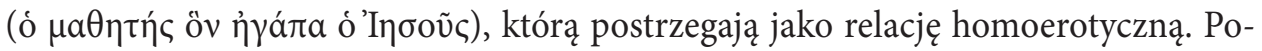

13 Zob. Goss, „The Beloved Disciple”, 212.

14 Zob. Wells, Strange Flesh (rozdział VIII: „Was Jesus Gay?”).

15 Artykuł został wycofany ze strony. Cytujemy jego fragment za Wells, Strange Flesh, rozdział VIII, przyp. 7: „Jesus loved Lazarus, Mary and Martha. What drew Jesus to this very non-traditional family group of a bachelor brother living with two spinster sisters? Two barren women and an eunuch are Jesus' adult family of choice. Are we to assume they were all celibate heterosexuals?".

16 Zob. Wilson, Outing the Bible, 111; Wells, Strange Flesh, ad loc.

17 Zob. Thayer, A Greek-English Lexicon of the New Testament, 5571, 5577.

18 Prawdopodobna jest też tutaj intencja zwrócenia uwagi czytelnika na ludzką wrażliwość Jezusa.

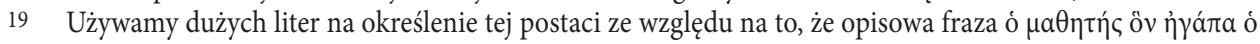

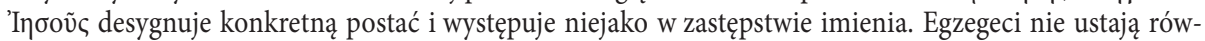
nież w wysiłkach identyfikacji owego ucznia z konkretną, znaną z imienia postacią. Propozycje te referuje np. Charlesworth, The Beloved Disciple (zwłaszcza pierwszy rozdział tej monografii). 
stać ta jest wzmiankowana kilkakrotnie w drugiej części czwartej Ewangelii (rozdziały 13-21). Po raz pierwszy spotykamy Umiłowanego Ucznia w Ewangelii Jana podczas ostatniej wieczerzy Jezusa z najbliższymi uczniami. Autor stwierdza, że w trakcie tego uroczystego posiłku Umiłowany Uczeń spoczywał na piersi Jezusa: „Spoczywał jeden z Jego uczniów na piersi Jezusa - ten, którego Jezus miłował”

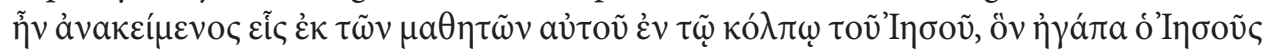
$(13,23)$. Na podstawie tej wypowiedzi niektórzy autorzy wyciągają wniosek o intymnej fizycznej homoseksualnej relacji Jezusa z owym uczniem ${ }^{20}$. Również w drugiej scenie Ewangelii Jana, w której pojawia się Umiłowany Uczeń (19,25-26), adwokaci tezy o homoseksualnej naturze Jezusa dopatrują się tego typu sygnałów. Otóż Umiłowany Uczeń stojący obok krzyża Jezusa jest przez nich widziany jako Jego kochanek, którego bliskość ceni On sobie nawet bardziej od relacji ze swoją Matką. Jennings we wspomnianej powyżej publikacji ujmuje to w następujący sposób:

Pełny sens tego epizodu wzmacnia naszą hipotezę, że Jezusa należy pojmować jako tego, który ma kochanka [...]. Relacja jest przedstawiona w tekście jako homoerotyczna, co jest tutaj potwierdzone poprzez wymaganie lojalności, która ma konsekwencje nawet po śmierci Jezusa [...]. Ta scena nie powinna być czytana jako podkreślająca miłość Jezusa do Matki (co nie jest sugerowane ani w tej, ani w innej Ewangelii), lecz miłość Jezusa do swojego umiłowanego ${ }^{21}$.

Trzeci epizod, w którym pojawia się Umiłowany Uczeń, to opowiadanie o przybyciu Piotra i Umiłowanego Ucznia do pustego grobu Jezusa (J 20,1-10). Jennings przyznaje, że nie ma tutaj żadnej przesłanki za homoseksualną naturą relacji Jezusa z Umiłowanym Uczniem. Stwierdza jednak, że przyjęcie takiej właśnie natury ich relacji pozwala lepiej zrozumieć trudną relację Piotra z Umiłowanym Uczniem²2.

Po raz ostatni Umiłowany Uczeń pojawia się w czwartej Ewangelii w opowiadaniu o objawieniu się zmartwychwstałego Chrystusa uczniom nad Jeziorem Tyberiadzkim (J 21). To on rozpoznaje w nieznajomym stojącym na brzegu zmartwychwstałego Pana i dzieli się tą informacją z pozostałymi sześcioma uczniami w łodzi $(21,7)$. On też idzie za Jezusem i Piotrem i jest przedmiotem ich rozmowy (21,22-23). Nie są wskazywane tutaj żadne wątki, które pozwoliłyby wysuwać przypuszczenie o homoerotycznej naturze relacji Jezusa i Umiłowanego Ucznia. Nie przeszkadza to jednak adwokatom tezy o homoerotycznej naturze relacji Jezusa z Umiłowanym Uczniem formułować konkluzji w stylu: „Z pewnością nie będziecie zdziwieni, że niektórzy

20 Zob. Goss, „The Beloved Disciple”, s. 211; Wells, Strange Flesh, ad loc.: „Here we have the actual physical intimacy of the beloved disciple with Jesus at the final farewell meal [...] The beloved disciple who rests in the kolpos is physically intimate with Jesus. The phrase en to kolpo used in the Septuagint translation of the Hebrew Scripture has a number of meanings, including an explicit sexual relationship".

21 Zob. Jennings, The Man Jesus Loved, 26-27.

22 Jennings, The Man Jesus Loved, 29. 
ludzie myślą, że był to rozwinięty homoerotyczny romans. Jezus i Umiłowany Uczeń byli gejowskimi kochankami”"23. „Relacja Jezusa z Umiłowanym Uczniem jest pederastyczną relacją starszego mężczyzny jako kochanka (erastes) z kochanym młodszym mężczyzną (eromenos)" 24 . „Jeżeli chcemy w pełni odczytać sens tego tekstu, to wydaje się, że Jezus miał kochanka tej samej płci”25.

Jak ocenić tego typu interpretacje biblijnego tekstu w świetle współczesnego stanu egzegezy? Wydaje się, że nawet czytelnik niewyposażony w wysublimowane narzędzia egzegetyczne z łatwością dostrzega, że mamy tu do czynienia z intelektualną nieuczciwością polegającą na wmawianiu tekstowi treści, których w nim nie ma. Na podstawie przedstawionej powyżej prezentacji poglądów na temat homoseksualnej natury relacji Jezusa z Umiłowanym Uczniem wyraźnie widać, że jedynym argumentem jest tu odczytanie stwierdzenia z J 13,23: „Spoczywał jeden z Jego

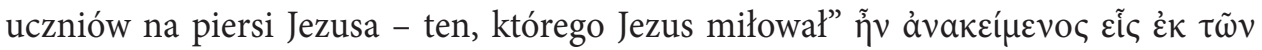

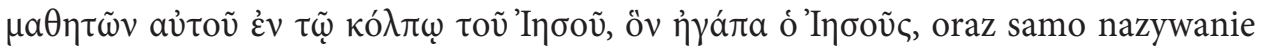
owego ucznia przez narratora (nie przez Jezusa!) Umiłowanym Uczniem.

Kluczowym argumentem za przypisaniem Jezusowi homoerotycznej relacji z Umiłowanym Uczniem jest gest jego spoczywania na piersi Jezusa podczas Ostatniej Wieczerzy. Dla właściwej interpretacji tego gestu konieczne jest prześledzenie,

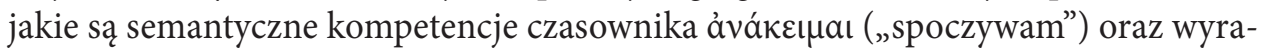

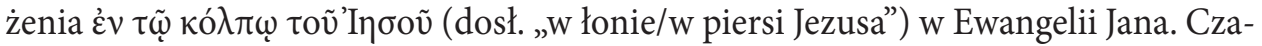

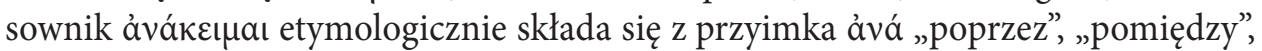
„W środku”, wyrażającego jako pierwotny przysłówek ideę „od dołu do góry”26, oraz

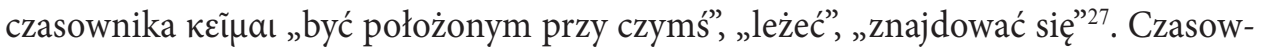

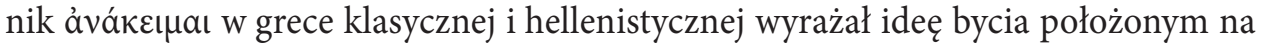
czymś, przypisanym czemuś, ofiarowanym komuś ${ }^{28}$. W odniesieniu zaś do osób używany był w kontekstach, w których chce się wyrazić myśl, że coś odnosi się do kogoś lub zależy od czyjejś woli ${ }^{29}$.

W Nowym Testamencie czasownik ten często desygnuje pozycję ciała przy spożywaniu posiłków ${ }^{30}$. Oznacza więc: „zajmować miejsce przy stole”, „spoczywać przy stole”, „zasiadać przy stole”. W Ewangelii Jana czasownik ảvákeı $\mu a$ jest użyty w 6,11a w narracji o rozmnożeniu przez Jezusa chleba i ryb dla nakarmienia tłumu

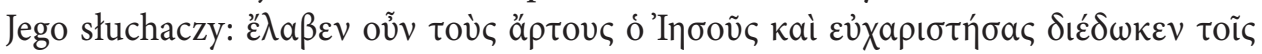

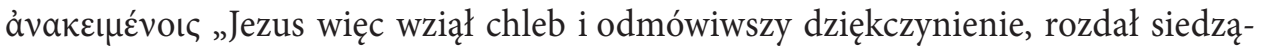

\footnotetext{
Zob. Wells, Strange Flesh, ad loc.

Zob. Goss, „The Beloved Disciple”, 208.

Sharpe, The Gay Gospels, ad loc.

Zob. Popowski, Wielki słownik grecko-polski Nowego Testamentu, 30-31.

Popowski, Wielki słownik grecko-polski Nowego Testamentu, 334.

Zob. Liddell - Scott - Jones, A Greek-English Lexicon, 2929.

Liddell - Scott - Jones, A Greek-English Lexicon, 2929.

Zob. Popowski, Wielki słownik grecko-polski Nowego Testamentu, 35.
} 


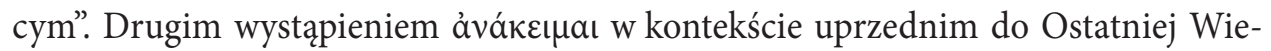
czerzy jest perykopa o uczcie Jezusa w domu Łazarza, Marty i Marii w Betanii, gdzie

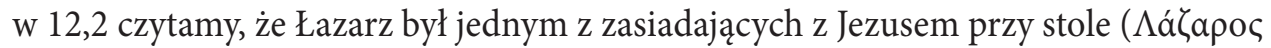

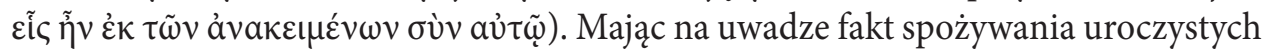
posiłków w kulturach basenu Morza Śródziemnego w owym czasie według wzorca triclinium, należy przyjąć, że w J 13 Jezus i uczniowie spożywali ostatnią wieczerzę

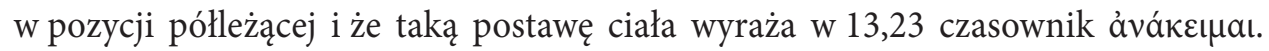

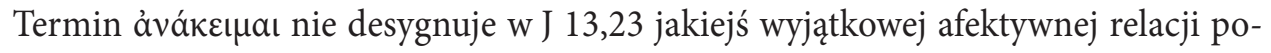
między Jezusem a Umiłowanym Uczniem, lecz oznacza, że spożywali posiłek, będąc obok siebie w pozycji półleżącej.

Koronnym argumentem używanym przez autorów tezy o homoerotycznej naturze relacji Jezusa z Umiłowanym Uczniem jest okoliczność, że w 13,23 jest powie-

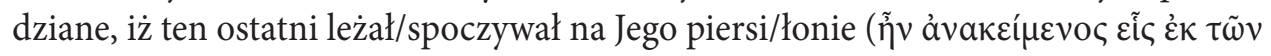

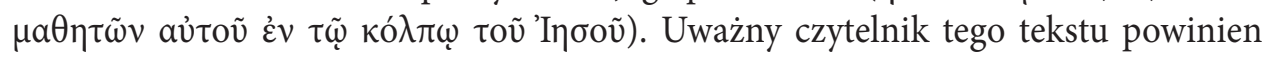
skonfrontować tę wypowiedź z tym, co autor pisze zaraz potem w 13,25: ảva

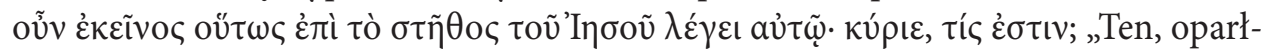
szy się więc na piersi Jezusa, powiedział do Niego: «Panie, któż to jest?»”. Jest to reakcja Umiłowanego Ucznia na pytanie, które kieruje do niego Piotr, dotyczące tego, kto spośród najbliższych uczniów zdradzi Jezusa $(13,24)$. Szczegóły te pozwalają wyciągnąć istotny wniosek odnośnie do interesującego nas zagadnienia: Umiłowany Uczeń nie mógł leżeć fizycznie na piersi Jezusa w 13,23, skoro w 13,25 jest mowa, że aby odpowiedzieć na pytanie Piotra, opiera się na chwilę na piersi Jezusa (forma

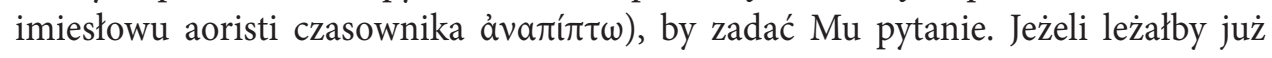
wcześniej na piersi Jezusa, to nie musiałby wykonywać tego gestu ${ }^{31}$. Należy zatem przyjąć, że Umiłowany Uczeń, spożywając Ostatnią Wieczerzę w pozycji półleżącej, znajdował się obok Jezusa ${ }^{32}$.

Nie rozwiązuje to jednak do końca problemu, gdyż w 13,23 autor literalnie pisze,

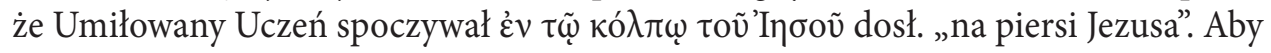
właściwie zinterpretować to wyrażenie, należy prześledzić znaczenia rzeczowni-

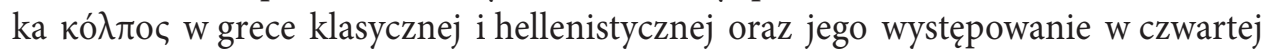
Ewangelii. Otóż rzeczownik ten w swoim podstawowym znaczeniu desygnuje „wgłębienie”, „wypukłość”, „zagięcie”. Termin ten określa zatokę w morzu (np. Dz 27,39), ale także np. sfałdowanie szaty nad pasem, stąd może oznaczać „fałd”, „zanadrze”,

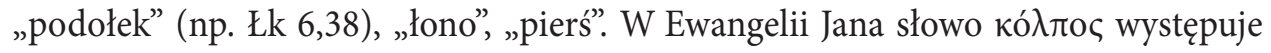
jedynie dwa razy. W takiej sytuacji można podejrzewać, że pomiędzy tymi wystąpieniami autor Ewangelii wprowadził intratekstualną zależność, która ma dać czy-

31 Zwracają na to uwagę również Innocent Hambiza, Adrian Schenker i Jean-Baptiste Edart (The Bible on the Question of Homosexuality, 112).

32 Tak interpretują J 13,23 np. Raymond E. Brown (The Gospel according to John XIII-XXI, 273-274) i Francis J. Moloney (The Gospel of John, 387). 
telnikowi niezawodny klucz interpretacyjny. Otóż jedynym wystąpieniem rzeczow-

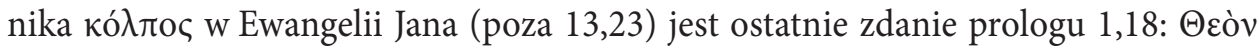

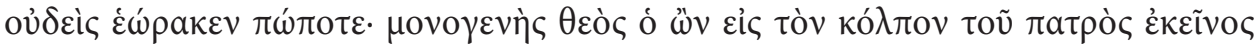

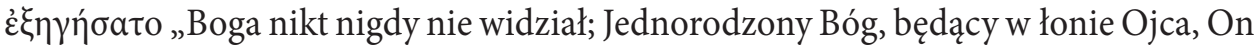
wyjaśnił" 33 . To zdanie (podsumowujące prolog 1,1-18, czyli paratekst, przy pomocy którego autor instruuje czytelnika, jak należy interpretować poszczególne perykopy i zawarte w nich motywy) mówi o relacji Jezusa z Bogiem Ojcem i o Jego misji

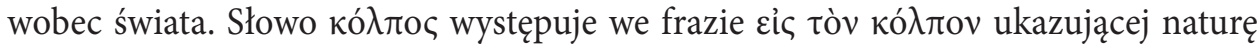
relacji Jezusa z Ojcem ${ }^{34}$. Jest On Logosem, Jednorodzonym Synem Boga, przebywa-

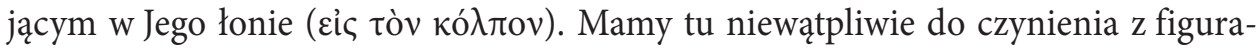

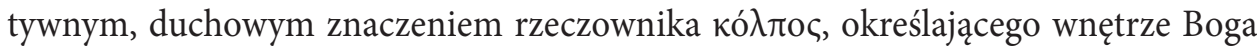
$\mathrm{Ojca}^{35}$. Przebywanie Syna w łonie Ojca oznacza najbardziej zażyłą, jaką można sobie wyobrazić, relację miłości Osób Boskich. Logos jest istotowo zjednoczony z Ojcem. Ten jakże ważki dla Ewangelii Jana motyw teologiczny znajdzie swoje liczne rozwinięcia w narracji czwartej Ewangelii i streści się w doskonały sposób w wyznaniu

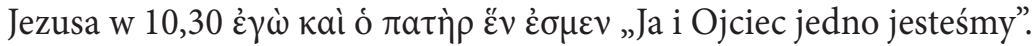

Wystąpienie rzeczownika kó $\lambda \pi$ roৎ w 1,18 jest hermeneutycznym kluczem do interpretacji jego znaczenia w 13,23. Przede wszystkim nadaje ono figuratywny charakter stwierdzeniu autora, mówiącego o tym, że Umiłowany Uczeń przebywał $\dot{\varepsilon} \nu \tau \tilde{\omega}$ kó $\lambda \pi \omega$. Chodzi tu zatem o wskazanie na niezwykle mocny duchowy charakter więzi łączącej Umiłowanego Ucznia z Jezusem. Jest to więź miłości, która ma się wzorować i realizować w idealnej relacji miłości Ojca z Synem. Wyraz kó $\lambda \pi$ đos definiuje zatem w 13,23 charakter relacji duchowej miłości, jaka ma łączyć każdego ucznia Jezusa z Nim samym, a przez Niego z Ojcem. Jest to zaproszenie wierzącego do uczestnictwa w głębi relacji miłości osób Trójcy Przenajświętszej. Na podstawie przedstawionych tutaj przesłanek można z całą stanowczością stwierdzić, że wyraże-

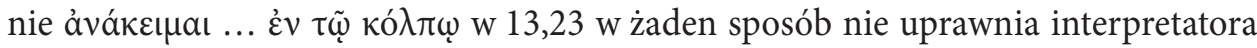
Ewangelii Jana do twierdzenia, że Jezusa łączyła z Umiłowanym Uczniem homoerotyczna relacja ${ }^{36}$.

Jak wskazaliśmy powyżej, przesłanką za wnioskowaniem o homoerotycznej rela-

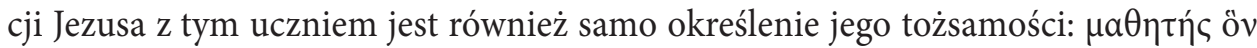

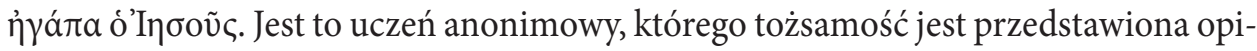
sowo: „uczeń, którego Jezus miłował”. Nie znajdujemy wzmianki o nim w pierwszej

\footnotetext{
33 Szersze wyjaśnienie tych powiązań znaleźć można np. w: Kręcidło, „Umiłowany Uczeń”, 111-126.

34 Bardzo wnikliwą i wszechstronną analizę tej frazy proponuje John F. McHugh (John 1-4 , 70-73).

35 McHugh, John 1-4, 71.

36 Warto także zwrócić uwagę na możliwe (drugoplanowe) znaczenie terminu кó $\pi$ roৎ w Ewangelii Jana odwołujące się do powszechnego na starożytnym Bliskim Wschodzie i w kulturze grecko-rzymskiej po-

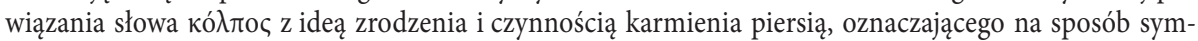
boliczny źródło istnienia i objawienia. Dla Jezusa źródłem tym będzie Ojciec $(1,18)$, dla Umiłowanego Ucznia - Jezus (13,23). Zob. Myers, „ «In the Father’s Bosom»", 481-497.
} 
części czwartej Ewangelii (rozdziały 1-12), będącej narracją o publicznej działalności Jezusa. Wyraźnie widać, że postać ta jest ukazana we wszystkich wspomnianych powyżej epizodach drugiej części Ewangelii jako wzorcowy model ucznia Jezusa ${ }^{37}$. Dlatego też interpretator nie powinien tracić egzegetycznej energii na dociekania zmierzające do utożsamienia tej postaci z którymś z krwi i kości uczniów Jezusa. Osoba ta jest zaproszeniem skierowanym do czytelnika, by stał się jak najdoskonalszym uczniem Jezusa, budując z Nim relację miłości na wzór owego ucznia idealnego. Jest to zaproszenie do miłości duchowej, wzorowanej na relacji miłości Ojca i Syna, niemającej żadnych konotacji homoerotycznych.

Pożyteczne wydaje się poruszenie tutaj jeszcze jednego wątku. W trzech spośród czterech epizodów, w których pojawia się Umiłowany Uczeń, jego tożsamość jest definiowana przy użyciu czasownika ả $\gamma a \pi a ́ \omega$, a jeden raz $(20,2)$ poprzez czasownik

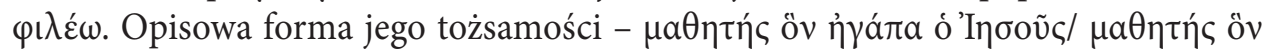

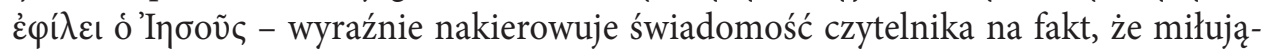
cym podmiotem jest tu Jezus. Określenia te nie mówią o miłości ucznia do Jezusa, ale o miłości, którą Jezus kocha każdego swojego ucznia (niezależnie od płci). Charakter

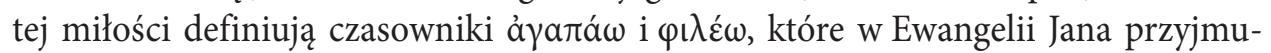
ją nacechowane znaczenia, odbiegające od generalnych dystynkcji, według których pierwszy z nich desygnuje miłość duchową, a drugi afektywną, emocjonalną więż́z ${ }^{38}$.

Szczegółowa analiza kontekstu występowania tych czasowników w czwartej Ewangelii pokazuje, że ả $a$ áá $\omega$ wyraża całe spektrum odcieni miłości duchowej, a także afektywną przyjaźn. Natomiast $\varphi \iota \lambda \varepsilon ́ \omega$, prócz swoich zwykłych kompetencji, konotuje w tej Ewangelii miłość radykalną, która wyraziła się w krzyżowej śmierci Jezusa za zbawienie swoich uczniów. Zatem związek składniowy „umiłowany uczeń”,

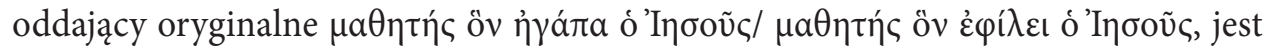
nośnikiem bardzo wysublimowanej myśli teologicznej odnośnie do radykalnej duchowej miłości Jezusa do każdego z uczniów, a nie informacji na temat homoerotycznej relacji Jezusa z nieznanym $\mathrm{z}$ imienia uczniem.

Podsumowując przedstawienie i krytyczną ewaluację poglądów autorów, którzy na podstawie wysoce stronniczej lektury niektórych fragmentów Ewangelii wysuwają twierdzenia o tym, że Jezus utrzymywał relacje homoseksualne z (1) bogatym młodzieńcem, (2) młodzieńcem, który szedł za Nim po pojmaniu Go w Getsemani, (3) z Łazarzem lub też z (4) Umiłowanym Uczniem, należy stwierdzić, że konstatacje te nie mają najmniejszych podstaw merytorycznych. Przeprowadzone analizy treści i kontekstu tych perykop nie pozwalają na doszukiwanie się w nich jakichkolwiek motywów homoerotycznych.

37 Natomiast w zakończeniu Ewangelii Jana Umiłowany Uczeń ujawnia czytelnikowi, że jest jej autorem $(21,21-24)$.

38 Odwołujemy się tutaj do wcześniej przeprowadzonych analiz, opublikowanych w: Kręcidło, „Piotrze, czy miłujesz mnie ponad wszystko?", 315-329. 


\section{Pośrednie argumenty za negatywną oceną aktów homoseksualnych przez Jezusa}

\subsection{Jezus podtrzymuje starotestamentowe nauczanie w kwestii relacji homoseksualnych}

Czytając Ewangelie kanoniczne w nie dość wnikliwy sposób, można odnieść mylne wrażenie, że nauczanie Jezusa jest radykalną kontestacją przepisów Tory oraz instytucji Starego Przymierza. W istocie jednak ewangeliści ukazują Jezusa jako praktykującego Żyda, który zasadniczo nie krytykuje przepisów Tory, lecz nadużycia w wypełnianiu Prawa. Zachowując tradycyjne Prawo, pokazuje drogę jeszcze doskonalszą ${ }^{39}$. Dla potwierdzenia tego spojrzenia przytoczyć można nauczanie Jezusa zawarte w Mt 5,18: „Nie sądźcie, że przyszedłem znieść Prawo albo Proroków. Nie przyszedłem znieść, ale wypełnić. Zaprawdę bowiem powiadam wam: Dopóki niebo i ziemia nie przeminą, ani jedna jota, ani jedna kreska nie zmieni się w prawie, aż się wszystko spełni" ${ }^{40}$. Co więcej w kontekście następnym tej wypowiedzi Jezusa z Kazania na Górze, tzn. w Mt 5,21-48, mamy serię sześciu antytez, w których Jezus nie tylko nie znosi uświęconych tradycją przepisów Prawa, lecz przenosi akcent $\mathrm{z}$ litery na wyższy, radykalnie duchowy poziom ${ }^{41}$. Za wyjątkiem trzeciej antytezy (5,31-32), pięć pozostałych rozpoczyna się od formuły: „Słyszeliście, że powiedziano..., a Ja wam powiadam.... Przykładem może być treść drugiej antytezy: „Słyszeliście, że powiedziano: Nie cudzołóż! A Ja wam powiadam: Każdy, kto pożądliwie patrzy na kobietę, już się w swoim sercu dopuścił z nią cudzołóstwa" (Mt 5,27-28). Ta ogólna obserwacja odnoście do stosunku Jezusa do przepisów Tory dotyczy również interesującej nas kwestii Jego oceny nadużyć w sferze (homo)seksualnej.

Można zatem wnioskować, że skoro Jezus nie wypowiada się nigdzie przeciwko wyrażonej w przepisach Tory starotestamentowej nauce odnośnie do sfery seksualnej człowieka, to przyjmuje te przepisy jako fundament swojego nauczania w tej materii ${ }^{42}$. Jakie było nauczanie Starego Testamentu i judaizmu przełomu $\mathrm{er}^{43}$ na temat seksualności człowieka, które Jezus afirmuje, a niekiedy również radykalizuje

\footnotetext{
39 Zob. Gagnon, The Bible and Homosexual Practice, rozdział III: „The Witness of Jesus”.

Zob. też tekst paralelny w Łk 16,17.

41 Zob. Theissen - Merz, The Historical Jesus, 364. Szerokie omówienie relacji nauczania Jezusa do ST na przykładzie pierwszej Mateuszowej antytezy prezentuje np. Kubiś, „Morderczy gniew”, 249-287.

42 Na potrzeby niniejszego artykułu nie dokonujemy rozróżnienia pomiędzy nauczaniem historycznego Jezusa a tym, jak relacjonują je autorzy Ewangelii kanonicznych.

43 Dla uzyskania pełnego obrazu tła nauczania Jezusa należałoby przedstawić, jak na te sprawy zapatrywały się różne nurty judaizmu w okresie międzytestamentowym. Z uwagi na zwięzłość wywodu, nie rozwijamy w artykule tego zagadnienia. Należy jednak mieć świadomość, że wielopostaciowy judaizm przełomu er utrzymuje starotestamentowe standardy etyczne odnośnie do homoseksualizmu. Świadectwa tego znajdujemy np. w: Filon Aleksandryjski, De Abrahamo 135-136; De specialibus legibus 3,37-39; De vita contemplativa 59-62; Flawiusz, Przeciw Apionowi 2,199; List Arysteasza 152; Testament Lewiego 17,11; Ksiegi Sybiliańskie 3,185-186; traktat „Sanhedryn” z Talmudu 7,4.
} 
w swoim nauczaniu? ${ }^{44}$ Fundamentem tego nauczania były dwa pierwsze rozdziały Księgi Rodzaju, gdzie seksualność człowieka jest widziana jako ustanowiona przez Boga i ma być sposobem kontynuacji Jego stwórczego dzieła ${ }^{45}$. Do takiej konstatacji dojść można na podstawie następujących stwierdzeń: „Stworzył więc Bóg człowieka na swój obraz, na obraz Boży go stworzył: stworzył mężczyznę i niewiastę" (Rdz 1,27) oraz „Bądźcie płodni i rozmnażajcie się, abyście zaludnili ziemię i uczynili ją sobie poddaną" (Rdz 1,28). W tej perspektywie seksualność człowieka jest darem Boga Stwórcy i udziałem w Jego stwórczej płodności. Każdy człowiek jest stworzony jako mężczyzna lub kobieta ${ }^{46}$, którzy są powołani do bycia płodnymi i rozmnażania się, stając się ,jednym ciałem" (Rdz 2,24). Jest to jedyny model relacji seksualnych uznawany w Starym Testamencie. Wszelkie inne „konfiguracje seksualne” są traktowane jako nadużycia i potępiane jako niezgodne $\mathrm{z}$ naturą porządku stworzenia ${ }^{47}$.

Żydowscy słuchacze Jezusa, wychowani w tamtej kulturze religijnej, nosili w sobie bez wątpienia ugruntowane przekonanie o tym, że akty homoseksualne są moralnie $\mathrm{zle}^{48}$. Ich myślenie na ten temat było formowane zarówno przez dydaktyczne biblijne narracje, jak i rygorystyczne przepisy religijnego prawa ${ }^{49}$.

Biblijną narracją, w której mamy do czynienia z negatywna oceną aktów homoseksualnych jest Rdz 19 - opowiadanie o zniszczeniu grzesznych miast Sodomy ${ }^{50}$ i Gomory. Interpretatorzy tego tekstu podkreślają, że zniszczenie tych miast przez Boga było rezultatem intencji zgwałcenia przez mężczyzn z Sodomy Bożych posłańców, których Lot przyjął w gościnę. Egzegeci różnią się jednak co do tego, czy bardziej chodzi tutaj o potępienie aktów homoseksualnych, czy też występku przeciw prawu gościnności ${ }^{51}$. Wydaje się, że w kontekście całej perykopy, a zwłaszcza kultury świata, w którym powstawały owe teksty, w Rdz 19 chodzi o zamiar gwałtu analnego, który miałby na celu poniżenie owych posłańców i podkreślenie panowania mężczyzn

44 Dobrą syntezę starotestamentowej nauki na temat homoseksualizmu przedstawiają np. Iwona Slawik i Jakub Slawik („Homoseksualizm problemem Kościoła?”, 14-36). Autorzy nie podejmują jednak problematyki postawy Jezusa wobec homoseksualizmu. Zob. też bardzo dobry ekskurs „Biblia a kwestia homoseksualizmu", Lemański, Księga Rodzaju. Rozdziały 11,27-36,43, 392-404.

45 Więcej na ten temat zob. Swartley, Homosexuality, 25-29.

46 Zob. Selmys, „Male and Female He Created Them”, 32-36.

47 Zob. Dresner, „Homosexuality and the Order of Creation”, 309-321; Dozeman, „Creation and Procreation", 169-191.

48 Christopher B. Zeichmann („Same-Sex Intercourse”, 13-36) przedstawia teksty m.in. Józefa Flawiusza, Tacyta oraz świadectwa graficzne z przełomu er z motywem mężczyzn żydowskich zaangażowanych w akty homoseksualne i proponuje, by w związku z tym na nowo spojrzeć na zagadnienie stosunku Jezusa do homoseksualizmu. Zamieszczone w tym artykule materiały nie są jednak w naszej opinii wystarczającą przesłanką za wnioskowaniem o bardziej otwartej postawie Jezusa wobec relacji homoseksualnych.

49 Szersze tło ukazuje np. Scroggs, The New Testament and Homosexuality, 66-98.

50 Wszechstronne studium biblijnego motywu Sodomy proponuje np. Michael Carden (Sodomy. A History of a Christian Myth).

51 Dyskusję na ten temat kompetentnie przedstawiają: Slawik - Slawik, „Homoseksualizm problemem Kościoła?", 27-29 (wraz z przypisami). 
z Sodomy nad nimi ${ }^{52}$. Lot gotów jest poświęcić dziewictwo swoich córek, gdyż gwałt seksualny na posłańcach mężczyznach ściągnąłby na niego, jako udzielającego im gościny, o wiele większą hańbę niż gwałt zadany jego córkom. Gwałt na mężczyźnie był bowiem społecznie odbierany jako jego feminizacja ${ }^{53}$. Choć potępienie aktów homoseksualnych nie wydaje się być pierwszorzędnym celem pragmatycznym autora $\operatorname{Rdz} 19$, to jednak bez wątpienia są tu one negatywnie oceniane.

Z podobnym jak w Rdz 19 problemem rozłożenia akcentów w interpretacji spotykamy się w Sdz 19,10-30, gdzie jest mowa o próbie dopuszczenia się aktów homoseksualnych przez mężczyzn z Gibea na lewicie, który wraz ze swoją żoną zatrzymał się na noc w gościnie u pewnego starca. Narracja ta zawiera liczne motywy wspólne z Rdz 19 (zwłaszcza wersety 1-11) ${ }^{54}$. Gdy do Gibea, miasta zamieszkałego przez Beniaminitów, przybył lewita wraz ze swoją żoną, spotkał się z brakiem gościnności. Udzielił mu jej dopiero pewien powracający z pola Efraimita. Niegodziwi mieszkańcy miasta zażądali wydania gościa lewity, aby z nim współżyć. Gwałt analny na lewicie byłby przestępstwem seksualnym ściągającym hańbę na niego samego (feminizacja) i na jego gospodarza. Jako mniejsze zło starzec proponuje im, by obcowali raczej z córką i żoną lewity, którą ten ostatni wyprowadza do nich. Po śmierci żony lewity wskutek gwałtu inne plemiona izraelskie dla zmazania jego hańby dokonują krwawej zemsty na Gibeonitach. Podobnie jak w przypadku Rdz 19, również w narracji Sdz 19 podstawowym kluczem interpretacyjnym wydaje się być kryterium honoru/hańby (wstydu). Bez wątpienia jednak akt współżycia seksualnego mężczyzn ze sobą jest tu widziany jako ciężkie przestępstwo o charakterze seksualnym (hebr. נְבְלָה w Sdz 19,23) $)^{55}$.

Niektórzy współcześni czytelnicy Biblii, szukając w niej potwierdzenia tez o akceptacji aktów homoseksualnych przez starotestamentowe tradycje, odwołują się do narracji Ksiąg Samuela, mówiących o bliskiej przyjaźni Dawida i Jonatana (1 Sm 18-20; 23,16-18; 2 Sm 1,26 $)^{56}$. Trzeba powiedzieć, że używane przez autora słownictwo, które na poziomie czysto filologicznym może mieć znaczenie erotyczne, nigdy w takim kontekście nie jest używane, gdy mowa jest o relacji tych młodych ludzi ${ }^{57}$. Jest to zawsze kontekst polityczny i religijny, i on ostatecznie determinuje znaczenie. Jest tu z pewnością mowa o głębokiej przyjaźni i braterskiej miłości

\footnotetext{
52 Slawik - Slawik, „Homoseksualizm problemem Kościoła?”, 28-29.

53 Slawik - Slawik, „Homoseksualizm problemem Kościoła?”, 29. Więcej na temat interpretacji tej perykopy w kontekście kwestii homoseksualności Napora, „«Mieszkańcy Sodomy byli źli...» (Rdz 13,13)”, 119-136.

54 Podaje je i analizuje m.in. Claus Westermann (Genesis 12-36, 362-363).

55 Zob. Slawik - Slawik, „Homoseksualizm problemem Kościoła?”, 31.

56 Zagadnienie to omawia szeroko Martti Nissinen („Die Liebe von David und Jonatan ”, 250-263). Zob. też: Zehnder, „Exegetische Beobachtungen ”, 153-179.

57 Nieco inaczej teksty te interpretują I. Slawik i J. Slawik („Homoseksualizm problemem Kościoła?”, 33-39).
} 
Dawida i Jonatana ${ }^{58}$. Nie ma żadnych przesłanek, by widzieć w ich wzajemnych gestach akty homoseksualne ${ }^{59}$.

W Księdze Kapłańskiej znajdujemy dwa przepisy Tory ${ }^{60}$, w których homoseksu-

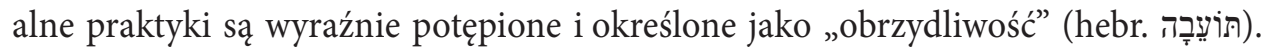
Pierwsza wypowiedź pochodzi z Kpł 18,22: „Nie będziesz obcował z mężczyzną, tak jak się obcuje z kobietą. To jest obrzydliwość”. Drugie zaś znajduje się w Kpł 20,13 i brzmi: „Ktokolwiek obcuje cieleśnie z mężczyzną, tak jak obcuje się z kobietą, popełnia obrzydliwość. Obaj będą ukarani śmiercią, ich krew na nich”. Obie wypowiedzi znajdują się w większym bloku przepisów prawnych Kpł 17-26, nazywanym Kodeksem/Prawem Świętości i obejmującym regulacje prawne dotyczące wszystkich sfer życia wyznawców judaizmu. Bezpośrednim zaś kontekstem uprzednim i następnym wypowiedzi Kpł 18,22 i 20,13 oraz pozostałych przepisów w Kpł 18-20 dotyczących życia społecznego, a zarazem argumentem za przestrzeganiem ich w życiu narodu, jest konieczność zdystansowania się od sposobu postępowania ościennych narodów i przyjęcia Bożej drogi życia. Jest to warunkiem dalszego istnienia narodu Bożego wybrania (zob. Kpł 18,3-4; 20,22-24). Zakaz aktów homoseksualnych jest tutaj jednym z elementów życia społecznego, który ma zagwarantować dalsze trwanie narodu Izraela i jego konsekrację Jahwe pośród narodów podległych zepsuciu wskutek idolatrii ${ }^{61}$. Drugim argumentem przeciw relacjom homoseksualnym, który można wywnioskować z kontekstu wypowiedzi Kpł 18,22 i 20,13, jest to, że akty takie są sprzeczne z celem aktów seksualnych, mianowicie z przekazywaniem życia poprzez wydanie na świat potomstwa. W tej perspektywie akty homoseksualne są widziane przez Prawo Mojżeszowe podobnie jak akty heteroseksualne podczas menstruacji. Trzecią perspektywą, w której należy interpretować wypowiedzi przeciw aktom homoseksualnym z Kpł 18,22 i 20,13 jest fakt występowania ich w kontekście takich możliwych nadużyć seksualnych, jak kazirodztwo $(18,6-18)$, cudzołóstwo $(18,20)$, cielesne obcowanie ze zwierzętami $(18,23)$. Każdy z takich aktów seksualnych zaburza harmonię życia rodzinnego i szerzej - społecznego.

Podsumowując tę część argumentacji, należy stwierdzić, że problematyka aktów homoseksualnych zajmuje explicite marginalne miejsce w refleksji etycznej Starego Testamentu $^{62}$. Teologicznie należy ją interpretować w kontekście stworzenia przez

58 Do podobnych wniosków dochodzi Janusz Lemański (Księga Rodzaju. Rozdziały 11,27-36,43, 400-402).

59 Zob. szczegółowe analizy i konkluzje sformułowane w: Himbaza - Schenker - Edart, The Bible on the Question of Homosexuality, 24-44; Dziadosz, „Braterstwo Dawida i Jonatana”. Thomas Römer („Homosexualität und die Bibel", 60-62) dopatruje się w relacji Dawida i Jonatana erotycznego zabarwienia.

60 Zob. Himbaza - Schenker - Edart, The Bible on the Question of Homosexuality, 46. Zob. też: Boswell, Christianity, Social Tolerance, and Homosexuality, 100-102; Strzałkowska, „Homoseksualizm”, 137-162.

61 Po tej linii idzie również w interpretacji tego tekstu antropolog Mary Douglas („Justice as the Cornerstone", 345-347).

62 Zob. Himbaza - Schenker - Edart, The Bible on the Question of Homosexuality, 5. Należy zgodzić się z T. Römerem („Homosexualität und die Bibel”, 58), który odwołując się do współczesnej wiedzy antropologicznej na temat ról społecznych mężczyzn (to, co aktywne) i kobiet (to, co pasywne) w starożytnym 
Boga mężczyzny i kobiety, powołanych do wspólnoty życia i płodności (Rdz 1-2). Jest to jedyny społecznie i teologicznie usankcjonowany model relacji małżeńskiej w Starym Testamencie. Zarówno omówione starotestamentowe teksty narracyjne, jak i przepisy prawne, w których pojawia się motyw aktów homoseksualnych, przedstawiają je jako grzeszne i godne potępienia. $Z$ faktu, że Jezus w swoim nauczaniu nie podejmuje bezpośrednio tej problematyki, należy wyciągnąć wniosek, że podtrzymuje w całej rozciągłości starotestamentowe nauczanie ${ }^{63}$.

\subsection{Pośrednie argumenty w nauczaniu Jezusa ${ }^{64}$}

Ewangeliczne narracje opowiadające o nauczaniu Jezusa na temat dopuszczalności rozwodu (Mk 10,1-12; Mt 5,31-32; 19,1-9; Łk 16,18) dają pośrednie argumenty odnośnie do braku akceptacji przez Jezusa związków homoseksualnych ${ }^{65}$. Narracje Mk 10,1-12 i Mt 19,1-9 zawierają Jego nauczanie podczas drogi do Jerozolimy przed pojmaniem. Gdy był już w granicach Judei razem z towarzyszącym Mu tłumem słuchaczy, faryzeusze, chcąc zdyskredytować Go wobec owego tłumu, zadali Mu podchwytliwe pytanie na temat dopuszczalności rozwodu ${ }^{66}$. Konfrontacja ta dokonała się według standardów tzw. gry o honor. Na pytanie, czy wolno mężowi oddalić żonę, Jezus odpowiedział pytaniem: „Co wam nakazał Mojżesz?” (Mk 10,3). Na co zripostowali, że „Mojżesz pozwolił napisać list rozwodowy i oddalićc7” (Mt 10,4). W odpowiedzi Jezus przytoczył dobrze znane im argumenty skrypturystyczne z Rdz 1-2: „Czy nie czytaliście, że Stwórca od początku stworzył ich jako mężczyznę i kobietę. I powiedział: Dlatego opuści człowiek ojca i matkę i złączy się ze swoja żona, i będa oboje jednym ciałem. A tak już nie są dwoje, lecz jedno ciało. Co więc Bóg złączył, człowiek niech nie rozdziela" (Mt 19,4-6; por. Mk 10,6-9). Jezus najpierw zacytował (teksty pochyłe) nauczanie z Rdz 1,27, a następnie 2,24. Według wersji Mateuszowej

świecie śródziemnomorskim, uzasadnia taki stan rzeczy faktem, że przyjęcie roli kobiecej w związku homoseksualnym byłoby dla mężczyzny degradujące: „Die besprochenen Texte reflektieren eine Konzeption von männlich als aktiv und weiblich als passiv, sowie die Idee, dass ein Mann, der beim Sex eine weiblische Rolle spielt, dadurch zu einer Frau degradiert wird".

63 Co więcej, jeszcze bardziej je radykalizuje, podobnie jak inne wykroczenia dotyczące sfery seksualnej. Zob. na ten temat: De Young, Homosexuality, 217-220.

64 Zob. krótkie wprowadzenie w to zagadnienie: De Young, Homosexuality, 215-220. Natomiast Randy Engel w swoim wszechstronnym omówieniu problematyki homoseksualizmu nie uwzględnia tematyki stosunku Jezusa do relacji homoerotycznych (zob. The Rite of Sodomy [strony 37-40 autor dedykuje problematyce homoseksualnej w Nowym Testamencie]).

65 Zob. Gagnon, The Bible and Homosexual Practice, 193-196.

66 W judaizmie czasów Jezusa dominowały dwie odmienne opinie oparte na interpretacji Pwt 24,1-4. Według zwolenników szkoły Szammaja jedynym powodem, który daje mężczyźnie prawo do rozwiedzenia się z żoną, jest jej seksualna niemoralność. Natomiast zwolennicy bardziej liberalnego podejścia identyfikowali się z poglądami szkoły Hillela, według której zapis prawny w Pwt 24,1-4 pozwala mężczyźnie oddalić żonę w przypadku jej jakiejkolwiek nieobyczajności.

67 Odniesienie do Pwt 24,1-4. Zobacz artykuł: Carros, „Le Lévitique condamnerait-il l’homosexualité?”, 27-49. 
tego wydarzenia Jezus wyjaśnia dalej, że mężczyzna, który oddala żonę i bierze inną popełnia cudzołóstwo, podobnie jak ten, który bierze za żonę oddaloną (Mt 19,9) ${ }^{68}$. Oponenci Jezusa nie znaleźli odpowiedzi wobec takiej radykalizacji nauczania. Gra o honor zakończyła się zwycięstwem Jezusa. W relacji Markowej tego wydarzenia cały epizod kończy się stwierdzeniem Jezusa: „Co więc Bóg złączył, tego człowiek niech nie rozdziela" $(10,9)$, który dopiero później, w domu, zapytany przez uczniów, wyjaśnia im, że jeżeli którekolwiek z małżonków rozstaje się z osobą, z którą zawarło związek małżeński, i wiąże się z kimś innym, popełnia cudzołóstwo. Zarówno mężczyzna, jak i kobieta są traktowani tak samo (inaczej niż w relacji Mateuszowej, według której prawo rozwodowe przysługuje tylko mężczyźnie).

Analizowane teksty w pośredni sposób mówią o stosunku Jezusa do relacji homoerotycznych. Jego odwołanie się do Rdz 1,27 i 2,24 nie pozostawia wątpliwości, że jedynym antropologicznym modelem relacji małżeńskiej jest związek mężczyzny i kobiety: „Stwórca od początku stworzył ich jako mężczyznę i kobietę” (Mk 19,4). Taka antropologia wyklucza poligamię oraz jakiekolwiek inne małżeńskie konstelacje płciowe - mężczyzna z mężczyzną lub kobieta $\mathrm{z}$ kobietą ${ }^{69}$. W kontekście uprzed$\operatorname{nim} \operatorname{Rdz} 2,24$ (począwszy od w. 18) autor biblijny wydaje się przekonywać, że żadne z ziemskich stworzeń (,istoty żywe” w. 19), które Bóg przyprowadzał do mężczyzny, nie daje mu kompletności. Dopiero kobieta, stworzona $\mathrm{z}$ wyjętego z niego podczas snu żebra, uzyskuje jego żywiołową aprobatę: „Ta dopiero jest kością z moich kości i ciałem z mego ciała!" (2,23a). Motyw żebra wyraźnie wskazuje na komplementarność natur mężczyzny i kobiety, którzy poprzez związek małżeński „stają się jednym ciałem" (Rdz 2,24). Oznacza to, że natura ludzka znajduje swoją pełnię i jedność jedynie w związku mężczyzny i kobiety. Nigdzie indziej w Biblii nie ma alternatywnego modelu antropologicznego, który sankcjonowałby jakikolwiek inny typ związków małżeńskich, jak tylko heteroseksualne ${ }^{70}$. Jezus w swoim nauczaniu afirmuje ten model jako jedyny.

Niebezpośredniego argumentu za brakiem akceptacji przez Jezusa aktów homoseksualnych dostarczają fragmenty Jego wypowiedzi, w których piętnuje zachowania seksualne określane greckim słowem ropveía. Rzeczownik ten desygnuje wszelką aktywność seksualną poza legalnym związkiem małżeńskim ${ }^{71}$. Dlatego też tam, gdzie się pojawia ${ }^{72} \mathrm{w}$ wypowiedziach Jezusa, jeżeli kontekst na to pozwala, może odnosić

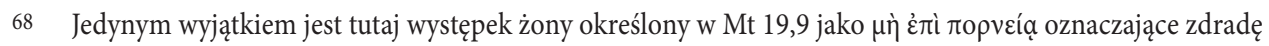
małżeńską. Ewangelista Marek w 10,1-12 nie podaje takiego zastrzeżenia.

69 Zob. Gagnon, The Bible and Homosexual Practice, 193.

70 Więcej zob. Lemański, „Człowiek jako mężczyzna i kobieta”, 97-118.

71 Zob. Popowski, Wielki słownik grecko-polski Nowego Testamentu, 516. Szerzej w: Arndt - Gingrich - Danker, A Greek-English Lexicon of the New Testament, 6089, 6090.

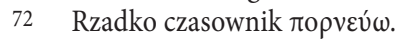


się także do czynności homoerotycznych ${ }^{73}$. Z takim przypadkiem mamy do czynienia np. w Mt 15,19: „Z serca bowiem pochodzą złe myśli, zabójstwa, cudzołóstwa ( stwa” oraz w paralelnym tekście Mk 7,21: „Z wnętrza bowiem, z serca ludzkiego

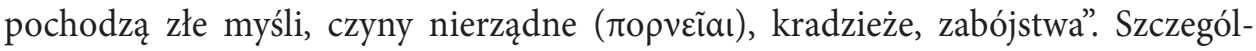

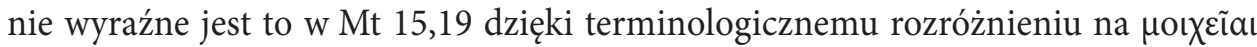
(oznaczające czyny cudzołożne) i ropveĩa (desygnujące wszelkie czyny nierządne, a zatem również akty homoseksualne). $\mathrm{W}$ tej samej perspektywie odczytać można analizowane powyżej wypowiedzi Mt 5,32: „A Ja wam powiadam: Każdy, kto oddala

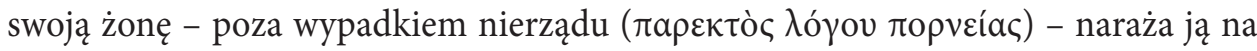

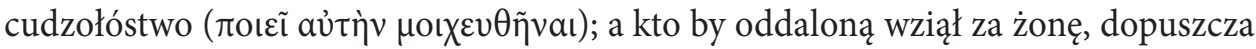
się cudzołóstwa ( $\mu$ oıxã $\tau \alpha$ )” i 19,9: „Powiadam wam: Kto oddala swoją żonę - chyba

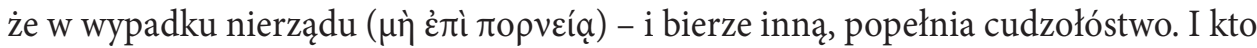

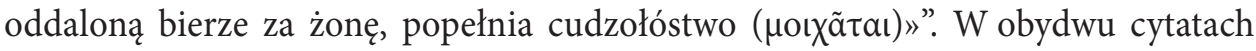
widać wyraźne dystynkcje terminologiczne pomiędzy zakresem znaczeniowym cza-

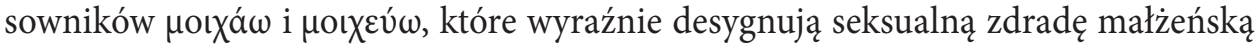

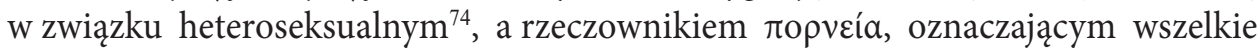
czyny nierządne zabronione przez Prawo Starego Testamentu, a zatem także akty homoreotyczne $e^{75}$.

Jednym z fragmentów Ewangelii kanonicznych, w którym niektórzy dopatrują się tolerancyjnej lub wręcz przychylnej postawy Jezusa wobec homoseksualizmu jest perykopa Łk 7,1-10. Traktuje ona o uzdrowieniu przez Niego na odległość ciężko chorego sługi rzymskiego centuriona z Kafarnaum. Dokonało się to na prośbę żydowskiej starszyzny miasta. Dla niektórych kluczową (jedyną) przesłanką dla wniosku, że Jezus miał przychylną postawę wobec relacji homoseksualnych, jest komentarz

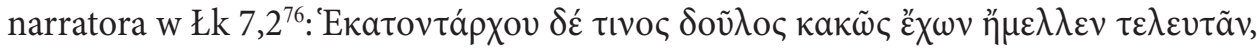

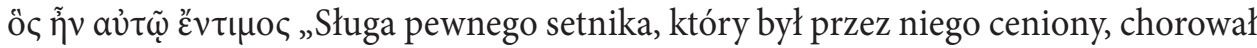
i bliski był śmierci”. Argumentacja za przychylną postawą Jezusa wobec relacji homoerotycznych prowadzona jest na podstawie zawężonego i niesłusznie nacechowanego

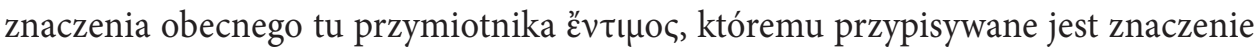

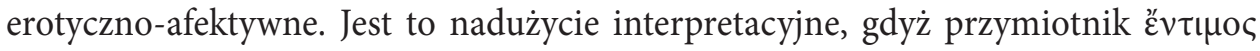
(oddany przez Hieronima w Wulgacie jako „pretiosus” - „cenny”) jest semantycznie

73 Ekkehardt Mueller (Homosexuality, Scripture, and the Church, 19) słusznie stwierdza: „[...] porneia has a wide range of meanings, including homosexuality. No first-century Jew would have spoken of porneiai (sexual immoralities) without having in mind the list of forbidden sexual offenses in Leviticus 18 and 20, particularly incest, adultery, same-sex intercourse, and bestiality".

74 Szerzej zob: Arndt - Gingrich - Danker, A Greek-English Lexicon of the New Testament, 4965, 4967.

75 Willard M. Swartley (Homosexuality, 40) fromułuje to w następujący sposób: „[...] certainly, in the first century Judaism homosexual intercourse would have been considered one of the worst of porneia offenses".

76 Tak utrzymuje np. amerykański były ksiądz katolicki, teolog i psycholog Daniel A. Helminiak w książce What the Bible Really Says about Homosexuality? 


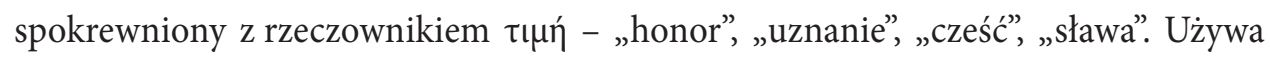
się go, gdy chce się podkreślić wysoką wartość, znaczenie osoby, do której się odnosi. W Łk 7,2 jest zatem przekazana czytelnikowi informacja, że rzymski setnik cenił swojego sługę. Z kontekstu całego epizodu wyraźnie wynika zaś, że musiał go cenić na tyle wysoko, iż zdecydował się posłać żydowską starszyznę do Jezusa, by prosić o uzdrowienie dla niego. Można się stąd domyślać (ale tylko domyślać), że nie chodzi tutaj tylko o cenienie owego sługi ze względu na jego wysokie kwalifikacje, lecz o życzliwość i łaskawość, którą centurion w stosunku do niego przejawiał. Nie ma jednakże w całym tekście Łk 7,1-10 ani też gdzie indziej w Ewangeliach najmniejszej przesłanki, która sugerowałaby czytelnikowi, że setnika i owego sługę łączyła relacja homoseksualna ${ }^{77}$. Perykopa $Ł k$ 7,1-10 jest zorientowana na pochwałę wiary centuriona ${ }^{78} \mathrm{w}$ uzdrowicielską moc Jezusa, wiary, która prowadzi do przezwyciężenia granic społecznych (Rzymianin - Żydzi, rzymski urzędnik - żydowski wędrowny nauczyciel z niższych warstw społecznych). Wiara ta wyraża się w aktywnej miłości bliźniego, a odpowiedzią na nią jest objawienie się uzdrowicielskiej i zbawczej mocy Chrystusa $^{79}$.

Jako argument za przychylną postawą Jezusa wobec relacji homoseksualnych podaje się niekiedy to, że akceptował On grzeszników, ubogich, chorych, nieczystych, wykluczonych przez system religijny związany z jerozolimską świątynią. Wyciąga się na tej podstawie niekiedy wniosek, że choć explicite na kartach Ewangelii nie ma mowy o akceptacji przez Jezusa osób o orientacji homoseksualnej, to można przypuszczać, że na pewno nie byliby przez Niego odrzuceni. Jest w takim myśleniu pewna pułapka, polegająca na braku rozróżnienia pomiędzy samą homoerotyczną orientacją/skłonnością a grzesznymi aktami homoseksualnymi popełnianymi przez osoby o tej orientacji ${ }^{80}$. Jezus w swoim nauczaniu z pewnością nie potępia grzeszników jako takich, ale negatywnie ocenia ich grzeszne czyny. Warunkiem przyjścia do Niego jest uznanie swoich grzesznych czynów, pokuta i nawrócenie („Idź, i od tej chwili już nie grzesz!”; J 8,11). Należy stąd wnioskować, że Jezus nie potępia samej orientacji homoseksualnej, na którą człowiek może nie mieć wpływu, nie akceptuje jednak aktów homoseksualnych. Ta fundamentalna zasada - rozróżnienia homoerotycznej skłonności od aktów homoseksualnych - powinna rządzić także praktyką duszpasterską Kościoła.

77 Szerzej na ten temat zob. Hambiza - Schenker - Edart, The Bible on the Question of Homosexuality, 107-110.

78 Luke T. Johnson (The Gospel of Luke, 120) słusznie podkreśla wielkość wiary rzymskiego setnika w Jezusa w porównaniu z wiarą starszyzny izraelskiej.

79 Zob. Hambiza - Schenker - Edart, The Bible on the Question of Homosexuality, 107-110. 


\section{Podsumowanie i wnioski}

W niniejszym artykule wysunęliśmy tezę, że pomimo iż Ewangelie kanoniczne nie podają żadnego wydarzenia ani wypowiedzi Jezusa, w których explicite podejmowałby problematykę homoseksualizmu, to jednak można $\mathrm{z}$ całą pewnością dojść do wniosku o Jego negatywnej ocenie aktów homoseksualnych. Wykazaliśmy najpierw, podejmując polemikę $\mathrm{z}$ autorami przypisującymi Jezusowi homoseksualną tożsamość na podstawie tendencyjnej egzegezy ewangelicznych perykop, że teksty te nie dają żadnych podstaw do takich wniosków. W dalszej części artykułu uargumentowaliśmy, że choć Jezus nie wypowiadał się w swoim nauczaniu explicite przeciw aktom homoseksualnym, to jednak Ewangelie dają pełną podstawę do wnioskowania, że takich aktów nie akceptował. Wykazaliśmy, że nauczanie Jezusa w tym względzie jest całkowicie osadzone w starotestamentowej etyce, utrzymywanej w wielopostaciowym judaizmie okresu Drugiej Świątyni. Monogamia heteroseksualna postrzegana tu była jako jedyny dopuszczalny model. Podejście to zasadniczo różniło się od poglądów i praktyk w tej materii w dominującej kulturze hellenistyczno-rzymskiej owego czasu. Pokazaliśmy także, że nauczanie Jezusa (a na poziomie Ewangelii - pierwotnego Kościoła) w zakresie etyki jest w niektórych aspektach bardziej radykalne, niż wymagały tego starotestamentowe przepisy prawa. W zakresie życia małżeńskiego dotyczy to zwłaszcza radykalizacji prawa rozwodowego, a w zakresie etyki seksualnej - oceny moralnej cudzołóstwa oraz wszelkich czynów nierządnych

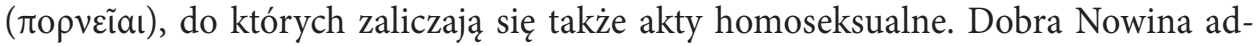
resowana przez Jezusa do grzeszników nie jest wyrazem tolerancji wobec nich, lecz wezwaniem do porzucenia grzesznych czynów i przyjścia do Niego. Wszelkie akty nierządne, do których zaliczają się także czyny homoseksualne, są oceniane przez Niego jako grzeszne.

\section{Bibliografia}

Arndt, W.F. - Gingrich, F.W. - Danker, F.W., A Greek-English Lexicon of the New Testament and Other Early Christian Literature (Chicago 2000) [BibleWorks 10].

Boswell, J., Christianity, Social Tolerance, and Homosexuality. Gay People in Western Europe from the Beginning of the Christian Era to the Fourteenth Century (Chicago: University of Chicago Press 1980).

Brown, R.E., The Gospel according to John XIII-XXI. A New Translation with Introduction and Commentary (Anchor Bible 29a; New York: Doubleday 1970).

Carden, M., Sodomy. A History of a Christian Myth (London: Equinox 2004).

Carros, G., „Le Lévitique condamnerait-il l'homosexualité? De l'exégèse à l'hermeneutique”, Sciences religieuses 38 (2009) 27-49. 


\section{JANUSZ KRĘCIDŁO}

Charlesworth, J.H., The Beloved Disciple. Whose Witness Validates the Gospel of John? (Valley Forge, PA: Trinity Press International 1995).

De Young, J.B., Homosexuality. Contemporary Claims Examined in Light of the Bible and Other Ancient Literature and Law (Grand Rapids, MI: Kregel 2000).

Donahue, J.R. - Harrington, D.J., The Gospel of Mark (Sacra Pagina 2; Collegeville, MN: Liturgical Press 2002).

Douglas, M., „Justice as the Cornerstone. An Interpretation of Leviticus 18-20”, Interpretation 53 (1999) 341-350.

Dozeman, T.B., „Creation and Procreation in the Biblical Teaching on Homosexuality”, Union Seminary Quarterly Review 49 (1995) 169-191.

Dresner, S.H., „Homosexuality and the Order of Creation”, Judaism 40 (1991) 309-321.

Dziadosz, D., „Braterstwo Dawida i Jonatana. Obraz męskiej przyjaźni w 1 Sm 18 - 2 Sm 1”, Verbum Vitae 39/1 (2021) 163-198.

Engel, R., The Rite of Sodomy. Homosexuality and the Roman Catholic Church. I. Historical Perspectives from Antiquity to the Cambridge Spies (Export, PA: New Engel Publishing 2011).

France, R.T., The Gospel of Mark (New International Greek Testament Commentary; Grand Rapids, MI: Eerdnams 2002).

Gagnon, R.A.J., The Bible and Homosexual Practice. Text and Hermeneutics (Nashville, TN: Abingdon Press 2010).

Goss, R.E., „The Beloved Disciple: A Queer Bereavement Narrative in a Time of AIDS”, Take Back the Word. A Queer Reading of the Bible (red. R.E. Goss - M. West) (Cleveland, OH: Pilgrim 2000) 206-218.

Helminiak, D.A., What the Bible Really Says about Homosexuality? (San Francisco, CA: Alamo Square Press 2000), wyd. polskie: Co Biblia naprawdę mówi o homoseksualności? (Gdynia: Uraeus 2002).

Himbaza, I. - Schenker, A. - Edart, J.-B., The Bible on the Question of Homosexuality (Washington, D.C.: Catholic University of America Press 2012).

Jennings, T.W., The Man Jesus Loved. Homoerotic Narratives from the New Testament (Cleveland, OH: Pilgrim 2003).

Johnson, L.T., The Gospel of Luke (Sacra Pagina 3; Collegeville, MN: Liturgical Press 1991).

Kręcidło, J., „Piotrze, czy miłujesz mnie ponad wszystko? Propozycja alternatywnej interpre-

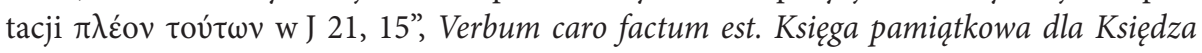
Profesora Tomasza Jelonka $w$ 70. rocznice urodzin (red. R. Bogacz - W. Chrostowski) (Warszawa: Stowarzyszenie Biblistów Polskich 2007) 315-329.

Kręcidło, J., „Umiłowany Uczeń jako świadek autentycznej wiary w Jezusa”, Studia Bobolanum 3 (2014) 111-126.

Kubiś, A., „Człowiek czy anioł? Tożsamość młodzieńca w Markowej narracji o pustym grobie Jezusa (16,5-7)", Przegląd Tomistyczny 21 (2015) 385-420.

Kubiś, A., „Morderczy gniew. Intertekstualna lektura Mt 5,21-22”, Verbum Vitae 34 (2018) 249-287. DOI: https://doi.org/10.31743/vv.2018.34.10

Lemański, J., Księga Rodzaju. Rozdziały 11,27-36,43. Wstęp - przekład z oryginału - komentarz (Nowy Komentarz Biblijny. Stary Testament 1/2; Częstochowa: Edycja Świętego Pawła 2014). 
Lemański, J., „Człowiek jako mężczyzna i kobieta. Fundamenty antropologii biblijnej, ich źródła i konsekwencje", Verbum Vitae 39/1 (2021) 97-118.

Liddell, H.G. - Scott, R. - Jones, H.S., A Greek-English Lexicon. A New Edition Revised and Augmented Throughout (Oxford 1968) [BibleWorks 10].

Malina, B.J. - Rohrbaugh, R.L., Social-Science Commentary on the Synoptic Gospels (Minneapolis: Fortress 2003).

McHugh, J.F., John 1-4. A Critical and Exegetical Commentary (London: Clark 2014).

Moloney, F.J., The Gospel of John (Sacra Pagina 4; Collegeville, MN: Liturgical Press 1998).

Mueller, E., Homosexuality, Scripture, and the Church (Silver Spring, MD: Biblical Research Institute 2010).

Myers, A.D., „ «In the Father's Bosom»: Breastfeeding and Identity Formation in John's Gospel”, Catholic Biblical Quarterly 76 (2013) 481-497.

Napora, K., „ «Mieszkańcy Sodomy byli źli...» (Rdz 13,13). Na czym polegał występek mieszkańców Sodomy?", Verbum Vitae 39/1 (2021) 119-136.

Nissinen, M., „Die Liebe von David und Jonatan als Frage der Moderne Exegese”, Biblica 80 (1999) 250-263.

Ostański, P., „Epizod o nagim młodzieńcu (Mk 14,51-52) na tle biblijnej nauki o nagości”, Teologia praktyczna 10 (2009) 209-223.

Perego, G., La nudità necessaria. Il ruolo del giovane di Mc 14,51-52 nel racconto marciano della passione-morte-risurrezione di Gesù (Cinisello Balsamo: Edizioni San Paolo 2000).

Popowski, R., Wielki słownik grecko-polski Nowego Testamentu (Warszawa: Vocatio 1994).

Römer, T., „Homosexualität und die Bibel”, Jahrbuch für biblische Theologie 33 (2018) 47-63.

Scroggs, R., The New Testament and Homosexuality. Contextual Background for Contemporary Debate (Philadelphia, PA: Fortress 1984).

Selmys, M., „Male and Female He Created Them”, The Catholic Answer 23 (2009) 32-36.

Sharpe, K., The Gay Gospels. Good News for Lesbian, Gay, Bisexual, and Transgendered People (Winchester, UK - Washington, D.C.: O-Books 2010).

Slawik, I. - Slawik, J., „Homoseksualizm problemem Kościoła?”, Rocznik Teologiczny 52/1 (2010) 9-69.

Spicq, C., AGAPH dans le Nouveau Testament (Paris: Gabalda 1959-1966) I-III.

Strzałkowska, B., „Homoseksualizm w świetle przepisów Tory”, Verbum Vitae 39/1 (2021) $137-162$.

Swartley, W.M., Homosexuality. Biblical Interpretation and Moral Discernment (Scottdale, PA: Herald Press 2003).

Thatcher, A., The Savage Text. The Use and Abuse of the Bible (Chichester, UK - Malden, MA: Wiley-Blackwell 2008).

Thayer, J.H., A Greek-English Lexicon of the New Testament [BibleWorks 10].

Theissen, G. - Merz, A., The Historical Jesus. A Comprehensive Guide (Minneapolis, MN: Fortress 1998).

Wells, S., Strange Flesh. The Bible and Homosexuality (SAB Books 2014) [EPUB].

Westermann, C., Genesis 12-36 (Biblischer Kommentar. Altes Testament 1/2; NeukiechenVluyn: Neukirchener 1981).

Wilson, N.L., Outing the Bible. Queer Folks, God, Jesus, and the Christian Scriptures (Indianapolis, IN: LifeJourney Press 2013). 


\section{JANUSZ KRĘCIDŁO}

Zehnder, M., „Exegetische Beobachtungen zu den David-Jonathan-Geschichten”, Biblica 79 (1998) 153-179.

Zeichmann, C.B., „Same-Sex Intercourse Involving Jewish Men 100 BCE-100 CE”, Religion and Gender 10/1 (2020) 13-36. 